\title{
RUBUS BOHEMO-POLONICUS (ROSACEAE) - A NEW SPECIES OF BRAMBLE FROM THE CZECH REPUBLIC AND POLAND
}

\author{
JERZY ZIELIŃSKI ${ }^{1}$, BOHUMIL TRÁVNÍČEK ${ }^{2}$ \\ ${ }^{1}$ Polish Academy of Sciences, Institute of Dendrology \\ Parkowa 5, 62-035 Kórnik, Poland \\ e-mail: jeziel@rose.man.poznan.pl \\ ${ }^{2}$ Department of Botany, Palacký University in Olomouc, Faculty of Science \\ Svobody 26, CZ-771 46 Olomouc, Czech Republic \\ e-mail: travnicek@prfholnt.upol.cz
}

(Received: June 1, 2004. Accepted: June 25, 2004)

\begin{abstract}
Rubus bohemo-polonicus Trávníček \& Zieliński, a regional species belonging to series Radula (Focke) Focke, is described from the Czech Republic and Poland. It differs from closely related species ( $R$. radula Weihe, $R$. salisburgensis Focke ex Caflisch and $R$. indusiatus Focke) mainly by the almost glabrous stems and consistently white petals. Illustrations and a distribution map of the new species are provided.
\end{abstract}

KEY WORDS: Central Europe, Czech Republic, Poland, Rubus bohemo-polonicus, Rosaceae, new species.

\section{INTRODUCTION}

During fieldwork in 1998-1999 to investigate the genus Rubus L. within the border areas of the Czech Republic and Poland, near the towns of Zlaté Hory, Prudnik, Głubczyce, Krnov and Opava, we observed on several occasions an interesting bramble belonging to series Radula (Focke) Focke. This same taxon we also found in other localities both in Poland and the Czech Republic so we conclude that it represents an as yet undescribed agamic species. This Czech-Polish bramble had already been collected several times by F. Spribille at the beginning of the previous century and labelled as $R$. radella in the herbarium (vouchers at WRSL); however, it has never been formally described.

\section{RUBUS BOHEMO-POLONICUS \\ B. TRÁVNÍČEK \& J. ZIELIŃSKI, SP. NOVA (Figs 1-2)}

Turio subangulatus, pilis nullis vel sparsis, setis glanduliferis multis usque $1(-1.5) \mathrm{mm}$ longis obsitus. Aculei ca. 8-12 ad $5 \mathrm{~cm}$, rectiusculi vel indistincte curvati, patentes vel parum reclinati, usque 5(-6) $\mathrm{mm}$ longi, basi abrupte dilatati, \pm aequales, in setae glanduliferae plerumque non transuent. Folia 3-5-foliolata, distincte pedata, supra obscure viridia, parce hirsuta, subtus griseo-viridia, pilis stel- latis sparsis vel numerosis obtecta. Foliolum terminale late ovatum usque suborbiculatum, acuminatum, acmodontum, dentes parvi, mucronati, vario modo directi. Stipulae filiformes. Inflorescentia conoidea, apice aphylla, foliis infimis 3-natis. Folia superiora subtus griseo-viridia, pilis stellatis \pm dense obtecta. Pedicelli 0.5-1.5 cm longi, dense breve pilosi, setis glanduliferis numerosis, aculeisque acicularibus usque 1-2.5 mm longis. Sepala grisea, setis glanduliferis obsita, in fructu reflexa. Petala alba, ca. $9 \mathrm{~mm}$ longa, basi in unguem longem abrupte angustata. Stamina stylos superantia. Antherae glabrae. Receptaculum parce pilosum. Germina parce pubescentia, saepe glabrescentia (VI-VII).

Typus: Southern Poland, eastern Sudeten Mts, near the village of Chomiąża SW of Głubczyce, $50^{\circ} 07^{\prime} \mathrm{N}$ -17³9'30' 'E, oak forest, 395 m, 17.07.2000, Kosiński, Tomaszewski \& Zieliński 158/2000, KOR 42783 (KOR holotype, OL isotype)

Plant usually up to $0.5 \mathrm{~m}$ tall, rarely taller. Sterile stems low-arching, rooting at apex, obtusely angular, with flat or convex sides, often purplish-brown, glabrous or rarely with scattered simple or tufted hairs, with \pm numerous (2-10 per $1 \mathrm{~cm}$ of stem length) stalked glands up to $1(-1.5) \mathrm{mm}$ long, with or without gland-tipped acicles and bristles. Prickles 8-12 per $5 \mathrm{~cm}$ of stem length, on angles or between them, 

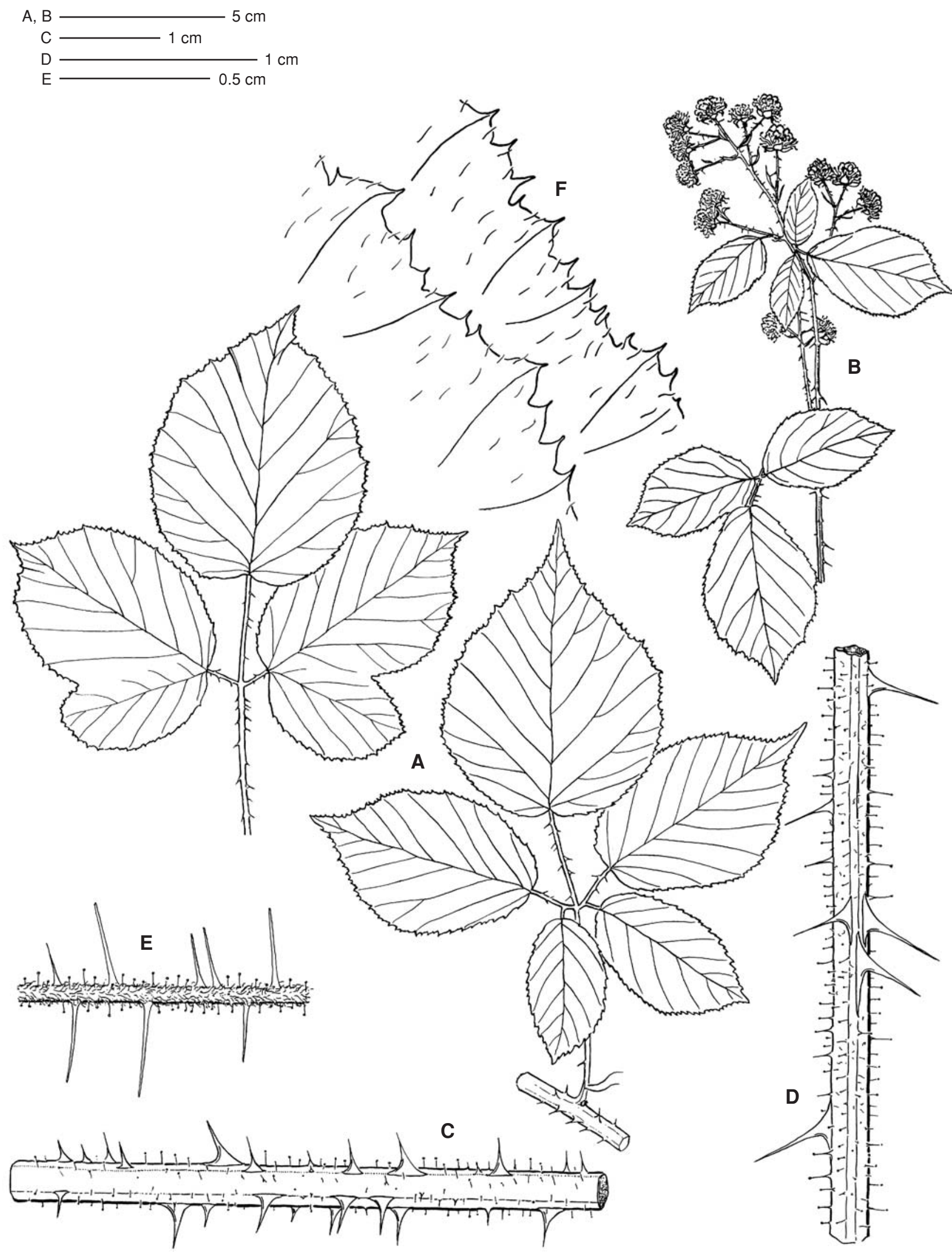

Fig. 1. Rubus bohemo-polonicus. A - leaves from sterile stem; B - inflorescence; C - part of sterile stem; D - part of inflorescence axis; E - part of pedicel; F - margins of terminal leaflets (all drawn from the holotype, Kosiński et al., KOR 42783). 
up to 5(-6) mm long, compressed and abruptly broadened at the base, straight or indistinctly curved, subpatent or somewhat declining, mostly \pm uniform, usually not grading into bristles and stalked glands. Leaves 3-foliolate and/or 4-5-foliolate, distinctly pedate, dark green, with few scattered simple hairs above, greyish beneath, with scattered simple hairs and with few to numerous stellate hairs but not markedly felted, smooth to the touch. Terminal leaflets on moderately long or long petiolules (petiolule $1 / 3-1 / 2$ as long as its lamina), broadly ovate to suborbicular, cordate or truncate at base, with acuminate apex up to $1 \mathrm{~cm}$ long, and unevenly serrate, with variously directed teeth; main teeth usually longer and retrorse; serration $2 \mathrm{~mm}$ deep. Petioles with (8-)10-15 straight or slightly curved, declining prickles up to $2.5(-3) \mathrm{mm}$ long and with stalked glands up to $0,8(-1) \mathrm{mm}$ long, sparsely pilose, flattened above. Stipules filiform, sparsely pilose, with stalked glands. Inflorescence conical, usually leafless and often truncate near apex, with 3-foliolate leaves below. Inflorescence leaves usually more densely stellate-hairy than those of sterile stems, the uppermost sometimes thinly felted, greyish-green beneath. Inflorescence axis sparsely hairy below, usually thinly stellate-hairy above and with rather numerous deep purple stalked glands. Simple and tufted hairs few, shorter than stalked glands. Prickles (6-)8-15 per $5 \mathrm{~cm}$ of axis length, up to $4(-5) \mathrm{mm}$ long, subulate, slightly curved or straight, declining, abruptly broadened at base, not grading into stalked glands. Pedicels $0.5-1.5 \mathrm{~cm}$ long, densely pubescent. Stalked glands numerous, longer (or sometimes shorter) than hairs and \pm equalling to or longer than width of pedicel. Pricklets 3-8(-10), needle-like, 1-2.5 mm long. Sepals greyish-felted, with stalked glands, reflexed after anthesis. Petals white, ca. $9 \mathrm{~mm}$ long, spathulate, long-clawed. Stamens longer than styles. Anthers glabrous, rarely with few hairs. Receptacle sparsely pilose. Ovary sparsely pubescent, often glabrescent. Flowering VI-VII (Fig. 1).

\section{Taxonomy}

$R$. bohemo-polonicus is a distinct species in series Radu$l a$. It is closely related to $R$. radula Weihe, from which it differs mainly by its glabrous stems, usually broader, more sharply serrate terminal leaflets and consistently white petals. $R$. bohemo-polonicus also resembles $R$. salisburgensis Focke ex Caflisch, but the latter species has hairy stems, usually smaller prickles, obtusely serrate to almost crenate terminal leaflets and pink petals. $R$. indusiatus Focke, a species occurring in Bavaria to southern Bohemia (Weber 1997; Holub 1999), differs from R. bohemo-polonicus by its hairy stems, leaflets simple-hairy beneath and pale pink petals (Fig. 2).

\section{Geographical distribution}

A regional species with its centre of distribution within a rather small area at the Czech-Polish frontier between the towns Prudnik, Głubczyce, Horní Benešov and Opava. There are only two isolated localities in eastern Bohemia (Fig. 3).

\section{Ecology}

$R$. bohemo-polonicus is a forest bramble. It grows in small oak woods, in open mixed oak and pine forests, often on former arable ground in planted pine forests. On account of its low stature it is often choked by more exuberant brambles. It is more abundant in rather dry places, in association with Calamagrostis epigejos (L.) Roth.

Our species was mentioned (as $R$. radellus) in the Red Data list of Czech vascular plants (Holub and Procházka 2000) as in category C3 ("threatened taxa"). It is, however, rather abundant and not threatened at all in its centre of distribution near the Czech-Polish frontier.

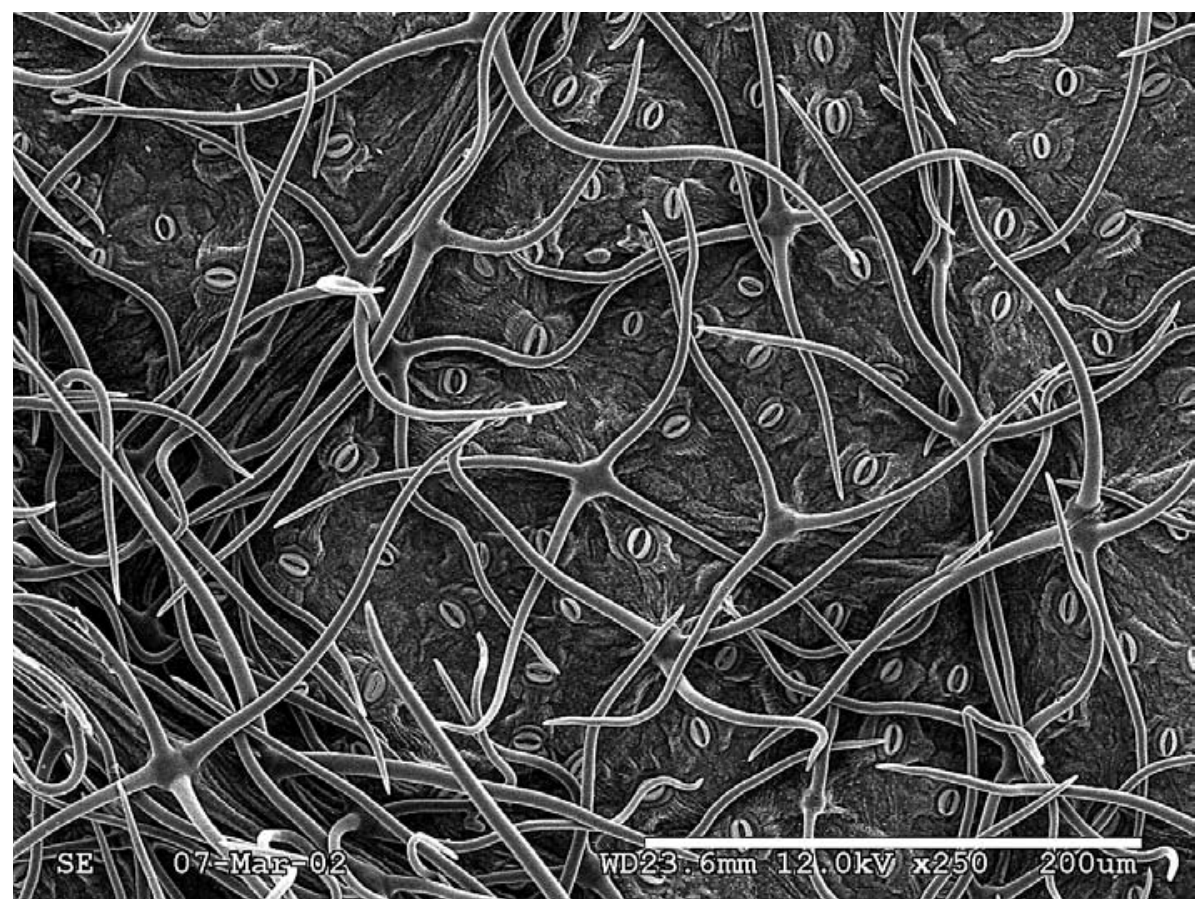

Fig. 2. Rubus bohemo-polonicus. Stellate hairs on the abaxial surface of terminal leaflet. Scale bar $=200 \mu \mathrm{m}$. (SEM, dry material coated with gold). Phot. D. Tomaszewski. 


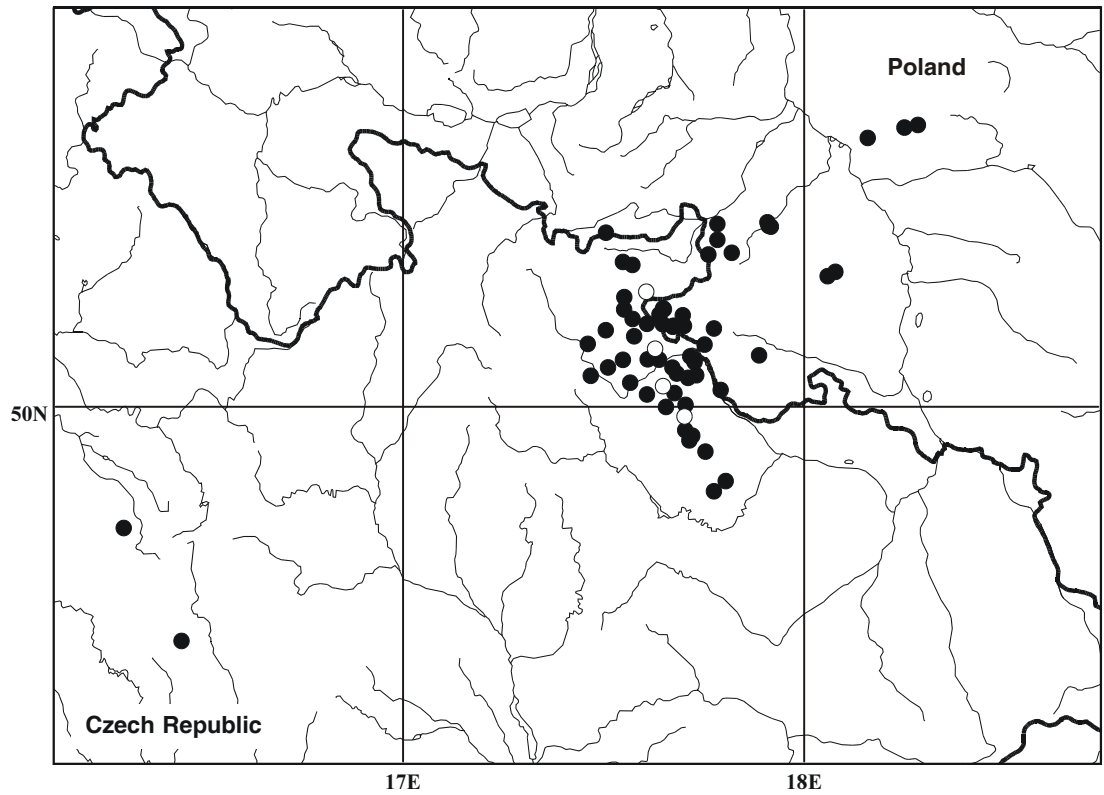

Fig. 3. Distribution map of Rubus bohemopolonicus (full dots - herbarium specimens, empty dots - field observations).

\section{Selected herbarium specimens}

\section{The Czech Republic}

(Phytogeographical districts after Skalický 1988)

Phyt. distr. 62. Litomyšlská pánev: Litomyšl, forest 1.7 km SE of the Pohodlí village, 18.07.2000, Trávníček (OL). - Phyt. distr. 63. Českomoravské mezihoří: Starý Svojanov (near Brněnec), forest at the road to Vítějeves, 08.09.2001, Trávníček (OL). - Phyt. distr. 74. Slezská pahorkatina: Jindřichov, forest margin along the road to Třemešná, 09.08.1999, Trávníček (OL); Zátor, wood N of the road to Lichnov, 13.09.2001, Trávníček (OL); Láryšov (near Krnov), wood at the crossroad $1.3 \mathrm{~km} \mathrm{NE}$ of the village, 08.08.1998, Trávníček (OL); Krnov, wood N of the Cvilín castle, 18.07.2000, Trávníček (OL); Úvalno, wood on the Strážiště hill $(395 \mathrm{~m})$, NW margin of the village, 02.10.1999, Pečinka (OL); Brumovice, forest along the road to Sosnová, 09.08.1998, Trávníček (OL); Sádek, forest margin, 1 km W of Sádecký Dvůr settlement, 09.08.1998, Trávníček (OL); Hlavnice, forest at the road to Nový Dvůr, 09.08.1998, Trávníček (OL); Near Nový Dvůr, forest margin, 350 m, 17.08.1993, Frank (AND, KOR); Mikolajice, forest along the road to Melč, $1.8 \mathrm{~km} \mathrm{SW}$ of the village, 13.09.2001, Trávníček (OL). - Phyt. distr. 75. Jesenické podhůří: Město Albrechtice, $2 \mathrm{~km}$ WNW of the railway station, 18.08.1999, Trávníček (OL); Hoštálkovy, forest along the path in the Kotel valley, $1.3 \mathrm{~km}$ W of the village, 18.08.1999, Trávníček (OL); Široká Niva, forest along the road to Čaková, $2 \mathrm{~km}$ E from church in the village, 13.09.2001, Trávníček (OL);

\section{Poland}

Distr. Opole: Nowa Wieś (Wieszczyna), by the road to Pokrzywna, 327 m, 29.07.1999, Kosiński \& Zieliński (KOR); Bliszczyce, $2 \mathrm{~km} \mathrm{~N}$ of the village, $388 \mathrm{~m}$, 12.09.1999, Kosiński \& Zieliński (KOR); Zubrzyce, 2 km
SW of the village, $307 \mathrm{~m}, 18.07 .2000$, Kosiński, Tomaszewski \&.Zieliński (KOR); Boboluszki, $320 \mathrm{~m}$, 19.07.2000, Kosiński, Tomaszewski \& Zieliński (KOR); Głubczyce, $4 \mathrm{~km}$ N of the town, 280 m, 20.07.2000, Kosiński, Tomaszewski \& Zieliński (KOR); Between Ciesznów \& Kazimierz, 27.07.1980, Szotkowski (KOR); NE of Pomorzowice, S of Racławice Śląskie, 26.08.1994, Zieliński (KOR); Near Czarnocin, 23.08.1902, Spribille (WRSL); Near Olszowa, 08.08.1908, Spribille (WRSL); Radoszowy, 07.08.1905, Spribille (WRSL).

\section{ACKNOWLEDGEMENTS}

We are much indebted to Dr Kit Tan, Copenhagen, for the linguistic improvement and correction of this article and to Dr Piotr Kosiński and Mr Dominik Tomaszewski, Kórnik, for technical assistance in preparing the map and SEM photograph.

The study was supported by the Comittee for Scientific Research of Poland (Grant no. BP04G 05217) and the Grant Agency of the Czech Republic (Grant no. 206/99/ 0771).

\section{LITERATURE CITED}

HOLUB J. 1999. Předběžný Červený seznam ostružiníků České republiky. Zpr. Čes. Bot. Společ. 34: 1-19.

HOLUB J., PROCHÁZKA F. 2000. Red List of vascular plants of the Czech Republic. Preslia 72: 187-230.

SKALICKÝ V. 1988. Regionálně fytogeografické členění. In: Květena České republiky. Hejný S., Slavik B. (eds), Academia, Praha. Vol. 1, pp. 103-121.

WEBER H.E. 1997. Untersuchungen zur Gattung Rubus L. im Chiemgau. Ber. Bayer. Bot. Ges. 68: 67-96. 